\title{
Breeding an Egg-Laying Poultry Strain Adapted to Puerto Rican Conditions
}

\author{
M. Rojas Daporta and A. González Chapel ${ }^{1}$
}

INTRODUCTION AND OBJECTIVES

Animal breeding work was started in Puerto Rico by the Agricultural Experiment Station in 1941 when plans were made for the establishment of projects for the development of dairy cattle, dairy goats, swine and poultry strains adapted to the conditions of the Island. The assumption underlying these projects was that livestock are subjected to detrimental environmental stresses under tropical and subtropical conditions, and that native stocks, through centuries of natural selection, are well-adapted to this adverse environment.

Ample evidence to support this assumption was available in the scientific literature. In 1935 Rhoad $(1)^{2}$ concluded that "the permanent solution of the farm dairy problems is not devising new ways of managing the old established breeds but rather the development of new breeds using the native type as foundation stocks". He stated further, in 1941 (2), that "the lack of adaptability of certain types of animals to tropical climatic conditions, as evidenced by discomfort, low production, and frequently degeneration in type, can be best overcome by breeding".

Several investigators have reported a depressing effect of high external temperature on growth $(3,4)$, egg size $(5)$, egg production $(6)$, egg quality $(7)$, and on broodiness ( 8 ). It has been also reported that the intensity and distribution of sunlight had a modifying effect on egg production $(9,10)$. Some breeds were found to be more tolerant of adverse climatic conditions than others $(9,10,11)$.

When the Station poultry project began in 1941, there were few commercial flocks in the Island, and the standard breeds were practically unknown to the farmers. Most of the poultry was raised in the open. No attempt was made to shield the birds from diseases or parasites, or from environmental stresses. This free-range system had certain advantages, mainly lower cost of feeding and facilities. The birds consumed insects and

1 Animal Husbandman and Assistant Director, respectively, Agricultural Experiment Station, University of Puerto Rico, Río Piedras, P.R. (Mr. A. González Chapel is on leave assigned to another agency.) This work, conducted with combined Federal and Commonwealth funds, was started under the supervision of Dr. E. E. Willet and continued by Dr. R. E. Comstock, A. González Chapel, and M. Rojas Daporta in that succession. Dr. D. Rivera Anaya was in charge of the veterinary work.

2 Italic numbers in parentheses refer to the Literature Cited, p. 476. 
plant seed, and no poultry housing was provided as shelter. No known systematic study to evaluate or improve the native fowl had then been conducted in Puerto Rico.

The objective of this project was to study the Native fowl under conditions of good management; to compare their productive capacity with that of standard breeds under similar conditions; and to study the possibility of improving them by selection or by grading-up.

By 1948 the evaluation of the Native stock had been completed and very limited improvement made under the controlled management followed (12). Efforts were then directed toward the development of adapted strains, both for the small farmers and the commerical egg-producer. In 1955 the project evolved towards the development of a strain adapted to egg production on specialized poultry farms.

\section{EXPLRIMENTAL PROCEDURE}

\section{LOCATION}

The work under this project was begun at the La Plata Valley in the central mountainous region of the Island. In 1951 it was continued at I ajas Valley in the southwestern part of the Island.

The Ia Plata Valley is a place of contrasting climatic conditions. Hot spells occur there during the summer months, but the winter months are chilly because of high relative humidity. The day and night cycle is somewhat contrasting also. The chill is felt at night, even during the summer months, while the daylight hours are mostly hot, frequently even during the winter season. In conclusion, the climatic conditions in Lal Plata Valley are rather hard on layers.

Lajas Valley is a dry region with a yearly average of 47 inches of illdistributed rainfall (10 years average), with only 15.5 inches registered during the first 6 months. The temperature ranges from a mean minimum of under $60^{\circ} \mathrm{F}$. during the winter to a mean maximum of slightly over $90^{\circ} \mathrm{F}$. during the summer (fig. 1).

\section{MANAGEMENT}

The baby chicks, that were hatched during the late winter and spring, were kept indoors in wire battery cages (fig. 2,A) until 2 months of age. They were then moved to houses with access to double rotational yards, the male and female kept apart. At the La Plata premises these houses were of the conventional closed-enclosure type used in southem United States. Since 19:2, low open sheds with a wire floor were used to rear the growing birds at Lajas.

At is months of age the pullets were moved to laying pens. These were 
open sheds with an elevated wire floor. The laying pullets were kept under confinement in $10 \times 10$-foot pens at Lat Plata. A smaller $8 \times 3$-foot unit was used at Lajas, with access to a double rotational yard (fig. 2,B).
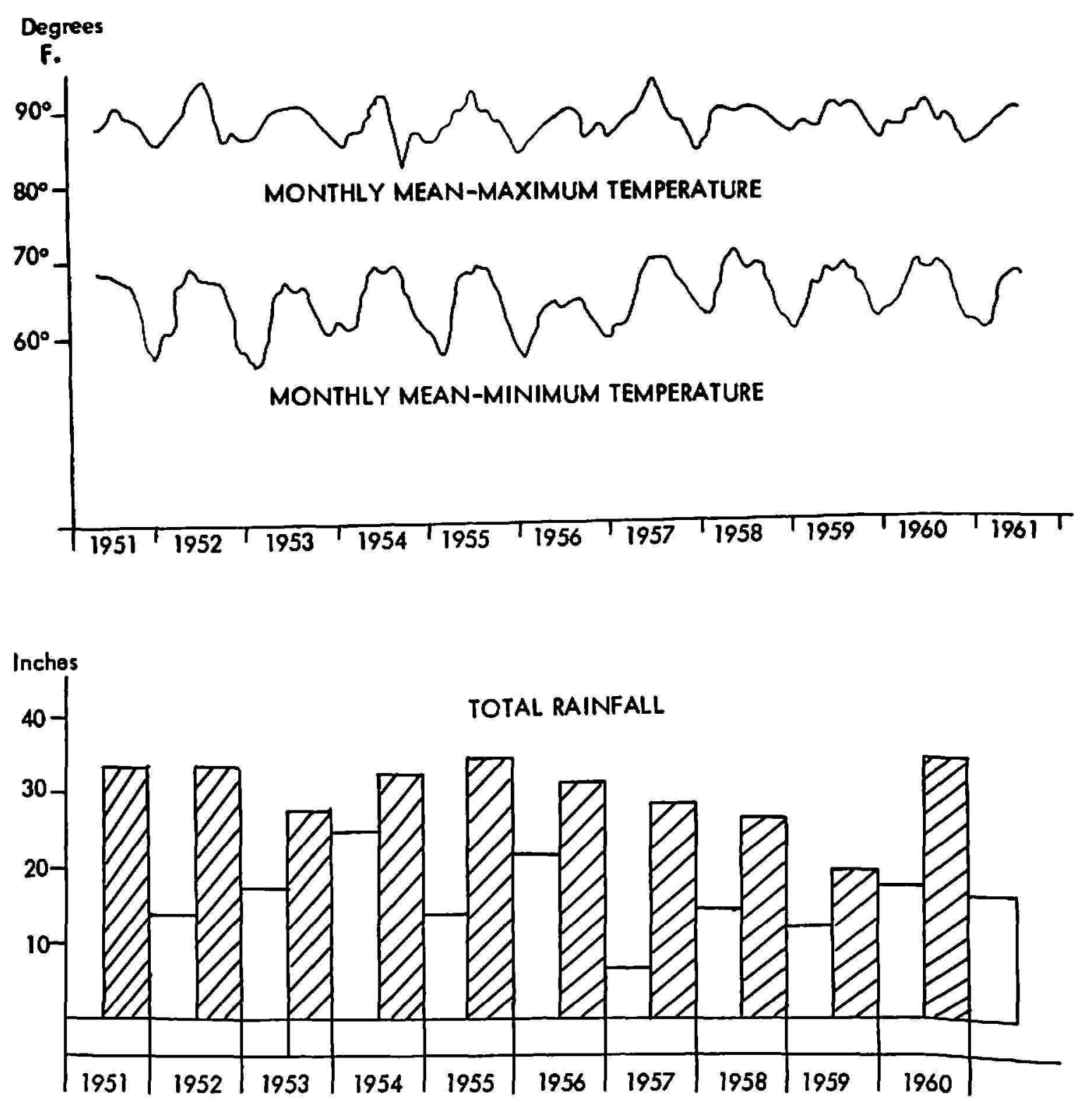

Fig. 1.-Monthly mean-maximum and mean-minimum temperature and total rainfall, first (dry) and second (wet) semesters, registered at the Lajas substation during a 10-year period, 1951-(i1.

Feed and water were always provided ad libitum. A starter and growing rat ion was given to the chicks until 2 months of age when they were changed 10 growing mash. Laying mash was started when the pullets were is mont hs of age. This contained 20 percent of protein up to $195 \overline{7}$, and 18 pereent thereafter. No supplement ary feeding was used.

vo preventive medication was pratised until antibiotios became a 


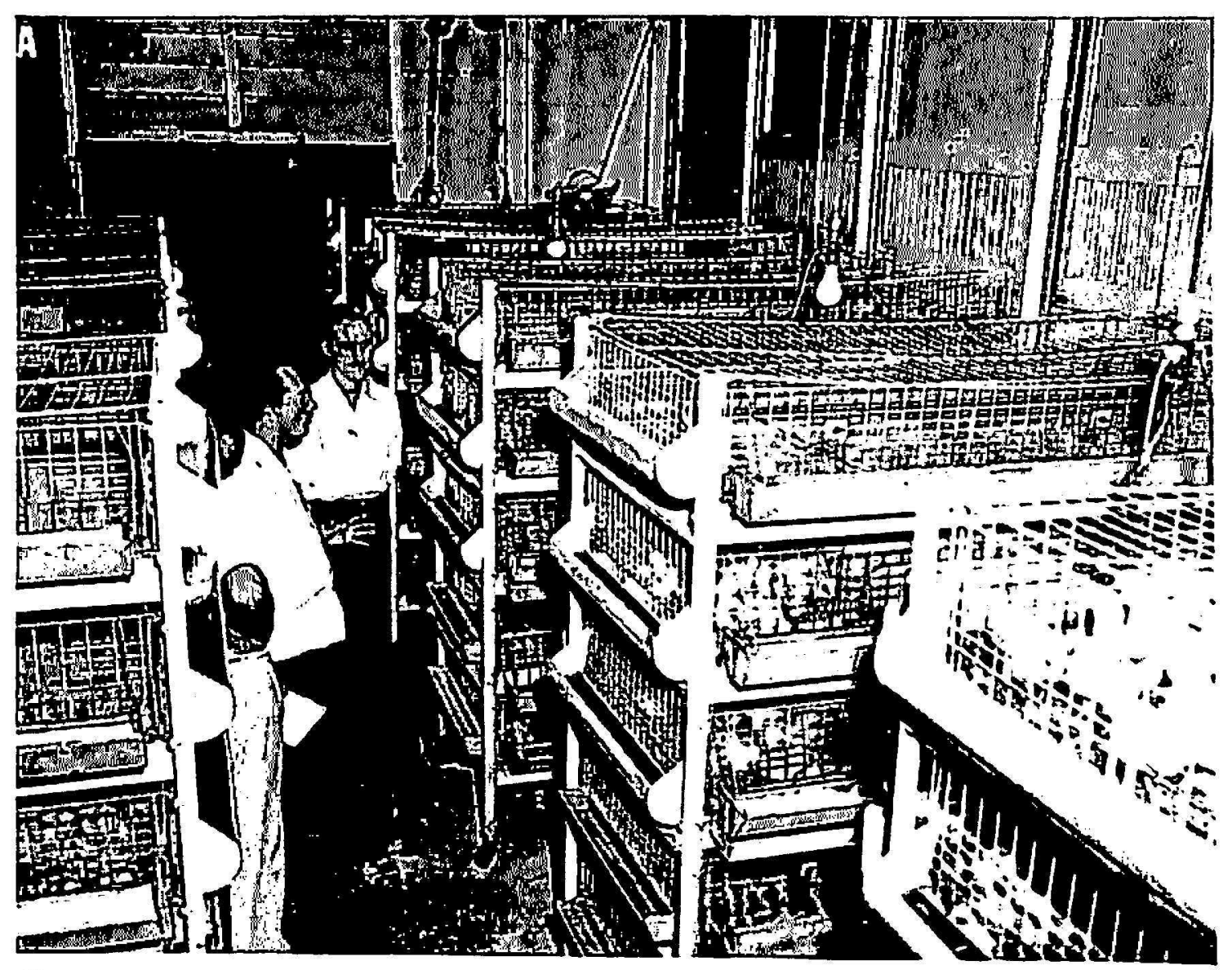

B

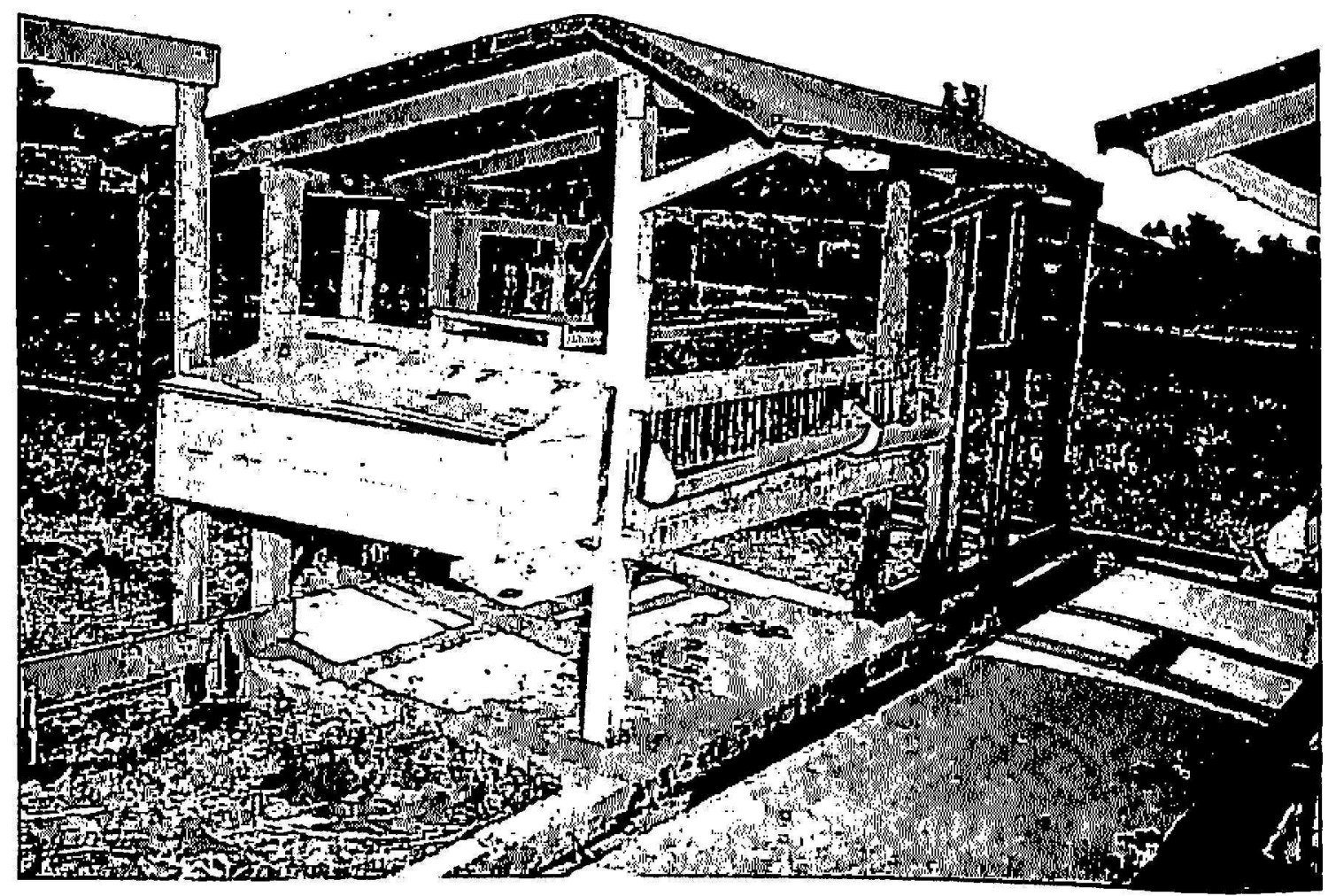

Fig. 2.- Rearing facilities used at the Lajas Substation: A, Battery brooders with removable heating units (replaced by modern brooders in 1954); B, laying pen with elevated wire floor and double rotational yards. 
routine ingredient in the commercial formulas used. Special protection against diseases, parasites, and environmental stresses was avoided as much as possible to expose the birds and provide some natural selection.

A heavy pullorum infection was detected in 1944, and stained antigen whole-blood tests were started during that year. The reactors and doubtful cases were removed immediately from the premises. By 1947 the disease appeared to be under control with only 3.5 percent of reactors, and close to zero thereafter.

Incidences of ocular leucosis started to be observed in 1950. The leucosis complex was also suspected in sporadic cases of paralysis and big-liver. The birds were examined for gray-eye (iritis) and the positive cases were eliminated as breeders.

A cholera attack took place in 1945 , but was controlled, mainly by sanitation and other preventative measures. Serious outbreaks of coryza occurred at Lit Plata in 1950 and at Lajas in 1952, which were successfully treated with streptomycin injections. A violent coccidiosis infection affected the growing population in 19:5is that motivated the use of coccidiostat in the feed formulas thereafter. Other limited and sporadic incidences of such diseases as roup and arthrit is were occasionally observed but, becausc of their localized or ephemeral nature, they do not warrant special mention.

\section{BREEDING; PROGRAN}

The project started with the use of two imported laying breeds and the Native fowl. New Hampshire and White Leghom birds were selected from a flock maintained by the Puerto Rico Reconstruction Administration at La Plata in 1941. They were compared with and considered superior to the Rhode Island, Plymouth Rock, and Light Sussex layers kept there. In the 1941-12 flock-year the New Hampshire hens laid at the rate of 53.5 percent, died at a 20.6-percent rate of mort ality during the laying year, and produced 45.8-gm. eggs during March. During that sime year the White Leghorns had a similar 53.0-percent rate of laying with a 19.4-percent rate of mortality, and a 47.3-gm. average egg weight during . March.

The native birds were obtained from small family flocks scattered throughout the Island, selected arerording to a specified standard of body aharacteristics.

A new strain of Rhode Island from the flock maintained by the College of Agriculture in Mayagüez was introduced into the breeding program in 19:54. This strain had been kept in the Island for several year's, and the birds were noted for large egg size.

The New Hampshire and White Leghorn hens were mated to Native rocks in 1943 and 1944, and their F, hirds wore mated inter-se and backcrossed to the three pure lines in 1945 and 1946. Further combinations were 
obtained by mating the most promising crossbreds among themselves. Later on, the New Hampshire was crossed with the Rhode Island strain brought from Mayagüez.

The straight Native stock and most of the crosses involving the Native were eliminated from the breeding flock because of undesirable laying performance; the purebred White Leghorn because of high mortality at the La Plata location.

By 1955, the surviving lines were the following: The purebred New Hampshire; the purebred Rhode Island; a New Hampshire-White Leghorn cross, backcrossed to the New Hampshire; the new Rhode Island-New Hampshire cross; and a 60-percent White Leghorn cross with Native.

All the lines were kept always under a strict closed-flock management.

\section{SELECTION PROCEDURES}

Throughout the period covered by this work the management procedure was such as not to preclude the application of selection pressure for resistance and adaptability. Special preventive measures and housing protection were avoided as much as possible, unless the flock was threatened as such.

The birds of the different strains were distributed as uniformly as possible in the hatching, rearing, and laying facilities to provide them as uniform an environment as possible. Efforts were also made to keep the management procedure uniform from year to year in order to measure progress.

The records taken included daily egg production and egg size (trapnesting), sexual maturity, monthly body weight during the growing period, and mortality.

Because of a heavy pullorum infection which forced a high rate of replacement, only mild individual selection for rate of laying was practiced up to 1946 . Family selection was started in 1947 , based on partial records during the laying pullet-year. The rate of replacement still remained high because of the need for increasing the number of birds in each line; thus the selection differential was still low (table 1). The laying period used for selection was increased gradually until full records could be depended upon by 1950 , when even progeny indices were available for the older stock. The variability for selection was increased by increasing the number of sires used per mating pen.

Up to 1955 the emphasis on selection was on rate of laying. Since then, selection for early sexual maturity and egg size was also practiced. In the later years a family index for total production to 500 days of age was used, thus including sexual maturity and rate of laying, and individual selection for egg weight was made within the selected families.

An effect of time of hatch on sexual maturity, linear when short hatching periods were used but with a curvilinear tendency when they extended to 
the early summer months, was found to affect the selection efficiency for sexual maturity specifically and for egg number to a certain extent (18). Hence an endeavor was made to shorten the hatching season so as to avoid the need for adjusting the records prior to selection. Since 1957 only eight weekly hatches were made for replacement.

\section{BREEDING LINES}

By 1955 the surviving lines in the project were as shown below.

TABLE 1.-Selection differentials within the New Hampshire flocks since

\begin{tabular}{|c|c|c|c|c|}
\hline \multirow{2}{*}{ Generation } & \multirow{2}{*}{ Flock year } & \multicolumn{2}{|c|}{ Combined dam-sire egg prod. ${ }^{2}$} & \multirow{2}{*}{ Difference } \\
\hline & & Selection mean & Flock mean & \\
\hline 8 & $1947-48$ & 122.5 & 115.0 & 7.5 \\
\hline 9 & $1948-49$ & 136.0 & 124.0 & 12.0 \\
\hline 10 & $1949-50$ & 167.3 & 138.5 & 28.8 \\
\hline 11 & $1950-51$ & 189.2 & 151.5 & 37.7 \\
\hline 12 & 1951-52 & 199.0 & 172.9 & 26.1 \\
\hline 13 & $1952-53$ & 209.6 & 179.1 & 30.5 \\
\hline 14 & $1953-54$ & 199.2 & 179.8 & 19.4 \\
\hline 15 & 1954-55 & 221.4 & 194.2 & 27.2 \\
\hline 16 & $1955-56$ & 194.7 & 177.1 & 17.6 \\
\hline 17 & $1956-57^{2}$ & 178.8 & 131.8 & 47.0 \\
\hline 18 & $1957-58$ & 170.8 & 154.8 & 16.0 \\
\hline 19 & $1958-59$ & 152.7 & 129.6 & 23.1 \\
\hline 20 & $1959-60$ & 154.5 & 139.7 & 14.8 \\
\hline
\end{tabular}

${ }^{1}$ No effective selection was practiced prior to 1947 , mainly because of disease problems.

${ }^{2}$ Up to generation 16 the records are based on eggs laid during the first laying year; to $\mathbf{5 0 0}$ days of age thereafter.

\section{NEW HAMPSHIRE}

The New Hampshire birds were maintained as a closed flock since 1941. From a 53-percent rate of laying during the first year of production, they had dropped to 37 percent by 1945 , mainly because of diseases. Since 1947, when family selection was started, a persistent and gradual recovery was noted and the layers reached the 53-percent level again by 1954 . Henceforth, this line will be identified as NH.

\section{NEW HAMPSHIRE-WHITE LEGHORN}

A cross was obtained between the New Hampshire and the White Leghorn that was eliminated as a pure line. It was backcrossed to the New 
Hampshire in 1950 and a good rate of laying was obtained, but the eggs were of small size. This line will be identified hereafter as NH-WL.

\section{WHITE LEGHORN-NATIVE}

A 60-percent White Leghorn cross with Native, available since 1948, was the only Native cross kept in the project. Even though consistently a poor layer, it was maintained because of its high family relationship and inbreeding. Because of the small number of layers involved, only individual selection was generally possible within this line. This line will be identified hereafter as WL-Native.

RHODE ISLAND

The Rhode Island from the flock of the College at Mayagüez was introduced into the breeding flock in 1954 and has been kept since under selection pressure. It was used mainly for crossbreeding purposes, mostly as a source of genes for large egg size. This line will hereafter be identified as RI.

\section{RHODE ISLAND-NEW HAMPSHIRE}

The College Rhode Island were mated to the Station New Hampshire in 1955. This Rhode Island-New Hampshire line was kept in the flock under a program of inter-se matings. Its fifth generation was produced in $\mathbf{1 9 6 0 .}$ This line will be identified hereafter as RI-NH.

\section{EVALUATION OF BREEDING LINES}

The lines of the project were evaluated among themselves using data from the last six flock-years.

\section{COMPARATIVE PERFORMANCE}

Figure 3 represents the production curve for five lines, the five RI-NH generations included, based on total number of eggs adjusted to a 2-ounce egg weight up to 500 days of age. This measure includes the three factors of production under selection pressure. The superiority of the RI-NH is well defined, but it tends to disappear with the progressive absence of its $F_{1}$ and inclusion of the subsequent generations.

The data obtained during 5 flock-years were analyzed statistically. These data included egg production to 500 days of age (the production of the survivers and henhoused average) and March egg weight (table 2). By analysis of variance it was found that the RI-NH was the superior line. All of its generations, $F_{1}$ to $F_{4}$, produced significantly more eggs than the other lines. The pure RI was superior only in egg weight.

A highly significant line-year interaction effect was also observed, mostly attributable to differences among the RI-NH generations. A contemporary 
comparison (table 3) produced an almost indentical ranking order as shown in table 2. This is a comparison of the differences obtained individually between each line and the total flock's weighted mean so as to eliminate the line-year interaction. Statistically significant differences were also obtained in all the $\mathbf{5}$ flock-years considered when taken individually.

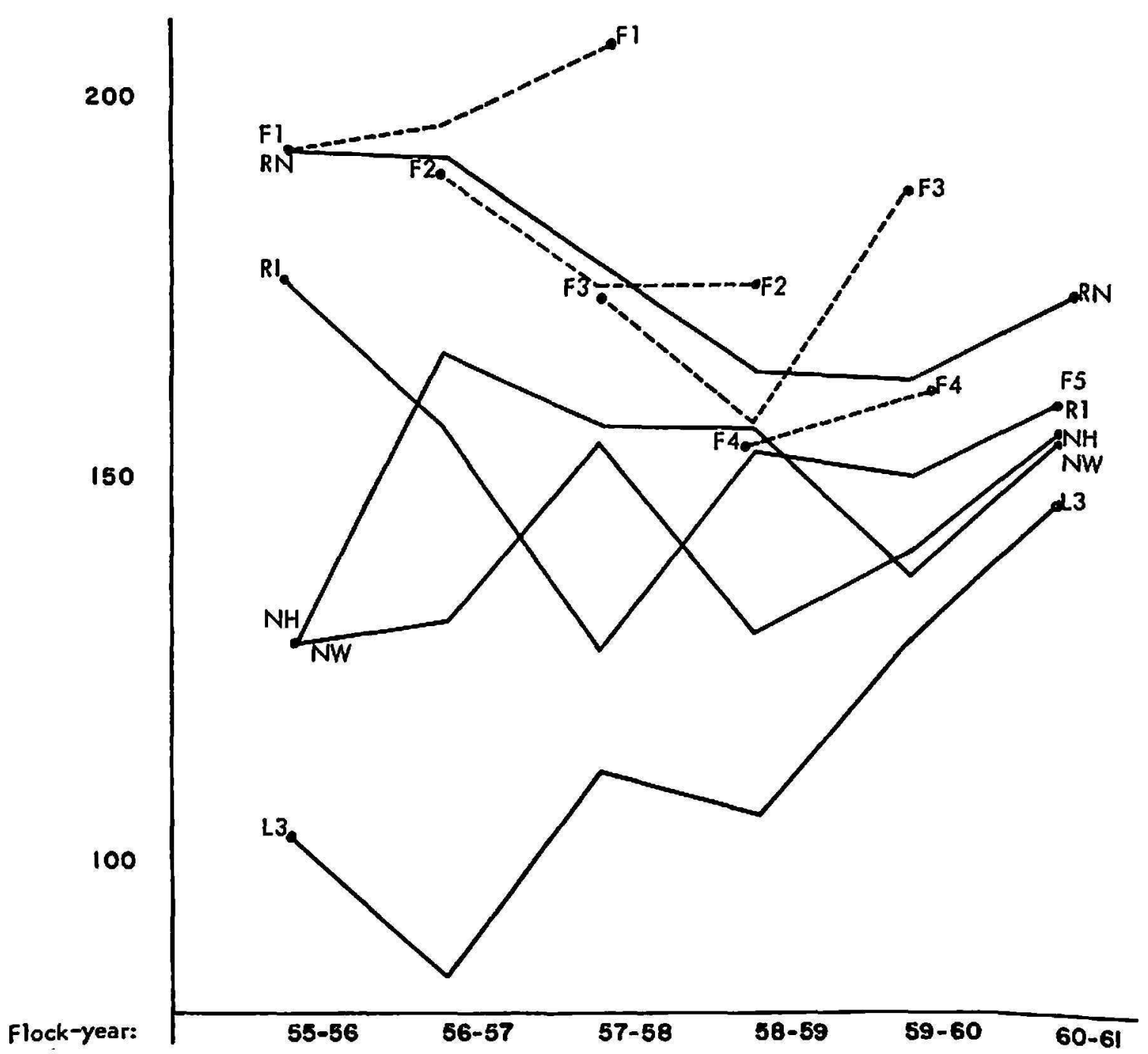

FIG. 3.-Production curve of 5 project lines, 5, RI-NH generations included, based on egg production adjusted to 2-oz. eggs, of the survivors to 500 days of age.

Table 4 shows the percentage viability for the different lines.

\section{EVALUATION AGAINST COMMERCIAL STRAINS}

The lines of the project were evaluated against three outstanding commercial strains, including De Kalb and Hy-Line hybrids, in 1957. Two tests were conducted, one under individual cage management and the other in small open pens like that shown in figure 2,B. The results are given in table 5. The differences in performance, viability in the cage test excepted, were not statistically significant. Thus, even though hybrids showed lower sexual 
TABLE 2.-Laying performance, weighted means for a 5-flock year period of the lines involved

\begin{tabular}{|c|c|c|c|}
\hline \multirow{2}{*}{ Line } & \multicolumn{2}{|c|}{ Egg production to 500 days age ${ }^{2}$} & \multirow{2}{*}{$\begin{array}{l}\text { March egg weight } \\
\quad(\text { oz. } / \mathrm{doz} .)\end{array}$} \\
\hline & Survivors & Henhoused & \\
\hline RI-NH $\mathrm{F}_{1}^{2}$ & 199.3 & 186.5 & 23.6 \\
\hline RI-NH $\mathrm{F}_{3}$ & 192.4 & 179.8 & 21.8 \\
\hline RI-NH $F_{2}$ & 185.2 & 174.2 & 22.6 \\
\hline RI-NH F & 173.6 & 155.4 & 21.6 \\
\hline NH-WL ${ }^{3}$ & 163.9 & 147.1 & 21.4 \\
\hline New Hampshire & 152.5 & 134.1 & 21.2 \\
\hline Rhode Island & 151.6 & 124.6 & 23.5 \\
\hline W.L.-Native & 127.1 & 109.9 & 19.8 \\
\hline
\end{tabular}

1 All the lines were superior at 1-percent probability to those lower in ranking order, with the following exceptions: No significance between NH and RI, nor between RI-NH $\mathrm{F}_{4}$ and NH-WL ${ }^{3}$ in egg production; between NH-WL and NH significance only at a 5-percent level.

${ }^{2}$ Rhode Island-New Hampshire crossbred (4 generations).

New Hampshire-White Leghorn crossbred.

4 White Leghorn-Native crossbred.

TABLE 3.-Contemporary comparison using the weighted means during a 5-flock-year period ${ }^{1}$

\begin{tabular}{l|r|r|r}
\hline \multirow{2}{*}{ Line } & \multicolumn{2}{|c|}{ Egg production to 500 days age } & $\begin{array}{c}\text { March egg weight } \\
\text { (oz./doz.) }\end{array}$ \\
\cline { 2 - 3 } & Survivors & Henhoused & \\
\hline RI-NH F ${ }^{2}$ & 38.2 & 43.1 & 2.2 \\
RI-NH F & 32.6 & 37.8 & .3 \\
RI-NH F & 24.8 & 31.9 & 1.2 \\
RI-NH F & 11.6 & 11.1 & .1 \\
NH-WL & 1.8 & 3.8 & -.2 \\
NH & -14.4 & -15.4 & -.5 \\
RI & -15.3 & -21.6 & 2.1 \\
WL-Native & -39.1 & -38.9 & -1.9 \\
\hline
\end{tabular}

1 Expressed as differences between each line's mean and the weighted mean for the entire flock.

${ }^{2}$ Rhode Island-New Hampshire crossbred, 4 generations.

maturity, larger eggs, and higher mortality, the results were not statistically conclusive.

\section{COMBINING ABILITY}

When mated to the RI-NH some of the project lines showed better combining ability than one commercial hybrid tested. An apparent effect of 
TABLE 4.-Percentage viability for the laying period to 500 days of age,1 1955-61

\begin{tabular}{l|c|c|c|c|c|c|c}
\hline \multicolumn{1}{c|}{ Line } & $1955-6$ & $1956-7$ & $1957-8$ & $1958-9$ & $1959-0$ & $1960-1$ & Total \\
\hline RI-NH & 67.3 & 68.0 & 76.5 & 62.5 & 78.3 & 71.4 & 70.7 \\
NH-WL & 72.9 & 77.8 & 82.9 & 73.2 & 76.9 & 78.9 & 77.1 \\
NH & 73.6 & 70.9 & $\mathbf{9 0 . 9}$ & 86.6 & 69.3 & 82.1 & 78.9 \\
RI & 52.2 & 60.6 & 93.9 & 92.9 & 72.7 & 62.3 & $\mathbf{7 2 . 4}$ \\
WL-Native & 80.4 & 86.0 & 94.6 & 76.2 & 89.2 & 74.0 & $\mathbf{8 3 . 3}$ \\
\hline
\end{tabular}

1 Since 5 months of age.

TABLE 5.-Comparative performance of several breeding and commercial lines in 2 tests, in individual cages and in open wire pens, at Lajas, P.R. ${ }^{1}$

\begin{tabular}{|c|c|c|c|c|c|c|}
\hline \multirow{2}{*}{ Line } & \multirow{2}{*}{$\begin{array}{c}\text { Sexual } \\
\text { maturity }\end{array}$} & \multicolumn{2}{|c|}{ Egg production } & \multirow{2}{*}{$\begin{array}{l}\text { Percentage } \\
\text { viability }^{2}\end{array}$} & \multirow{2}{*}{$\begin{array}{c}\text { Spring } \\
\text { egg } \\
\text { weight? }\end{array}$} & \multirow{2}{*}{$\begin{array}{c}\text { Feed } \\
\text { intakes }\end{array}$} \\
\hline & & Henhoused & Rate of lay & & & \\
\hline
\end{tabular}

Individual cage test

\begin{tabular}{l|c|c|c|c|c|c}
\hline Hy-Line & 159.2 & 158.2 & 61.2 & 71.4 & 58.7 & 0.289 \\
De Kalb & 152.1 & 158.1 & 60.8 & 71.4 & 51.3 & .289 \\
Cobb's Sex Link & 161.0 & 142.1 & 52.4 & 80.9 & 61.6 & .282 \\
RI-NH, F & 174.1 & 171.0 & 56.6 & 95.2 & 54.7 & .289 \\
RI-NH, F & 186.2 & 159.6 & 55.0 & 95.0 & 55.0 & - \\
WL-N x NH & 156.8 & 174.7 & 57.4 & $100.0^{2}$ & 51.8 & - \\
NH-WL & 180.7 & 163.4 & 54.0 & 95.2 & 51.0 & .255 \\
NH & 204.0 & 131.1 & 49.7 & 75.0 & 53.6 & .267 \\
\hline
\end{tabular}

Open wire pens with yards

\begin{tabular}{|c|c|c|c|c|c|}
\hline Hy-Line & 149.3 & 66.1 & 83.9 & 57.3 & 0.283 \\
\hline De Kalb & 148.9 & 60.3 & 70.4 & 56.4 & .284 \\
\hline Cobb's Sex Link & 145.8 & 58.7 & 87.0 & 57.6 & .328 \\
\hline RI-NH, F $_{1}$ & 160.5 & 60.9 & 90.0 & 55.3 & .285 \\
\hline RI-NH, $F_{2}$ & 131.6 & 57.1 & 72.7 & 54.4 & .263 \\
\hline $\mathrm{RI}-\mathrm{NH}, \mathrm{F}_{3}$ & 157.2 & 64.6 & 94.1 & & \\
\hline WL-N $\times$ NH & 171.0 & 58.2 & 83.3 & - & .240 \\
\hline NH-WL & 127.0 & 55.4 & 83.3 & 49.0 & .239 \\
\hline $\mathrm{NH}$ & 110.0 & 45.2 & 86.4 & 52.2 & .243 \\
\hline
\end{tabular}

1 Conducted by the Agricultural Experiment Station at the Lajas Substation during a 10-month experimental period.

2 Superior at a 1-percent level of probability.

3 Expressed in grams and pounds per hen-day, respectively. 
heterosis was also shown by a marked improvement of the crosses obtained over their parental lines.

Another example of hybrid vigor was observed repeatedly in a cross obtained between the New Hampshire and the White Leghorn-Native. Table 6 presents the results of that cross in 6 flock-years. It performed better than either parental line in egg production and sexual maturity in 5 of the 6 years presented.

The data in table 6 represent matings in which the New Hampshire female was used. When the reciprocal mating was used in the first 2 years

TABLE 6.-Combining ability between the White Leghorn-Native male and the New Hampshire female of the breeding flock at Lajas, P.R., 1953-61

\begin{tabular}{l|c|c|c|c}
\hline \multicolumn{1}{c|}{ Production factor } & Flock-year & $\begin{array}{c}\text { WL-Native } \\
\text { paternal line }\end{array}$ & $\begin{array}{c}\text { WL-NxNH } \\
\text { top cross }\end{array}$ & $\begin{array}{c}\text { NH } \\
\text { maternal line }\end{array}$ \\
\cline { 1 - 2 } Survival1 (first-year egg-laying) & $1953-54$ & 140.9 & 204.2 & 179.8 \\
& $1954-55$ & 131.8 & 245.8 & 194.4 \\
& $1955-56$ & 130.3 & 167.3 & 177.3 \\
& $1956-57$ & 117.5 & 196.3 & 169.8 \\
& $1957-58$ & 136.0 & 210.3 & 172.5 \\
Sexual Maturity (age in days at & $1960-61$ & 179.8 & 187.5 & 179.8 \\
1st. egg) & $1953-54$ & 247.3 & 200.7 & 245.0 \\
& $1954-55$ & 223.4 & 187.6 & 233.0 \\
& $1955-56$ & 195.2 & 179.0 & 223.7 \\
& $1956-57$ & 183.0 & 165.8 & 214.0 \\
& $1957-58$ & 194.3 & 156.7 & 207.2 \\
& $1960-61$ & 167.5 & 191.3 & 200.4 \\
\hline
\end{tabular}

1 Production during the laying year up to 1956-57, to 500 days of age during the last 2 flock-years.

presented, the birds started to lay 20.5 and 2.1 days later respectively, and laid 29.1 and 33.5 fewer eggs.

A desirable effect on egg production has been shown also when the New Hampshire is mated to the Rhode Island (see figure 5 and table 2).

\section{DISCUSSION AND CONCLUSIONS}

The breeding work reported here was initiated under the assumption that high-producing breeds or strains from temperate countries are subject in tropical regions like Puerto Rico to detrimental environmental stresses which largely curtail production. At the same time it was assumed that Native stocks, although traditionally poor layers under free-range management, could be improved under controlled management, or that they could 
contribute their assumed adaptability to crosses with imported stocks without greatly impairing productivity.

The Native fowl showed very little improvement when maintained under controlled good management. It was also found through this work that the contribution they could make toward an adapted high-producing poultry breed or strain would be negligible (12). Some evidence of seasonal effects on sexual maturity (13) and egg size (14) was recorded, but in most instances detrimental stresses could not be attributed to the natural environment. The New Hampshire strain, which was kept in the project throughout the whole period, showed evidence of deterioration up to 1947, but gradually recovered its initial productivity. It is probable that the prevalence of diseases such as pullorum in this initial period, followed by the limitations forced by them on the selection procedures, was the real reason for this deterioration.

Some of the lines developed during this project, particularly the Rhode Island-New Hampshire, could be used to advantage for commercial egg production in Puerto Rico, but a comparison of the project lines with imported commercial hybrids showed no clear-cut significant difference in performance.

Economically feasible improvements in rearing and housing (15), in feeding, and in disease control, have minimized considerably the limitations imposed on egg production by the natural environmental stresses in Puerto Rico. The availability of high-producing imported hybrids, which perform quite satisfactorily under properly managed farm conditions, renders the need for an adapted strain unnecessary.

From the experience gained through this work it is apparent that, in under-developed tropical and subtropical areas, the distinction between the man-made and the natural environment is not always clear, and that an improvement of the man-made environment, when economically feasible, more than offsets adverse climatic stresses, thus offering a shorter and more economical possibility than breeding for adaptability as a means of increasing livestock production.

\section{SUMMARY}

In 1941 the Puerto Rico Agricultural Experiment Station initiated a project for the development by breeding of an adapted egg-producing poultry strain for Puerto Rico. It was assumed that the Native stock was well adapted to the detrimental environmental stresses present under tropical and subtropical conditions. This Native stock was used, together with birds of the New Hampshire, White Leghorn, and later, Rhode Island, breeds as foundation material for crosses.

The purebreed Native and White Leghorn stocks were later on culled 
from the flock and, by 1955 , the surviving lines were: 1 , The New Hampshire; 2, a cross of the New Hampshire with the White Leghorn backcrossed to the New Hampshire; 3, a 60-percent White Leghorn-40-percent Native cross; 4, the Rhode Island; and 5, a cross between the Rhode Island and the New Hampshire.

A comparative evaluation of the existing lines showed the Rhode IslandNew Hampshire cross to be superior to the others in most of the productive characters. However, a comparison of the project lines with imported commercial hybrids failed to show significant differences in their performance.

It was found during this work that the contribution of the Native stock towards the project's objective would be negligible, and that economically feasible improvement in management conditions could offset most of the detrimental environmental stresses, so that high-producing imported hybrids could be used commercially in the Island.

It was concluded that, whenever the man-made conditions can be economically improved, this offers a better possibility than breeding for adaptability for increasing livestock production in tropical and subtropical areas.

\section{RESUMEN}

La Estación Experimental Agrícola de la Universidad de Puerto Rico inició en 1941 un proyecto para desarrollar una gallina ponedora de alta producción. Se presumía que la gallina Nativa estaba bien adaptada a condiciones ambientales desventajosas propias de los trópicos; y ésta, conjuntamente con las gallinas de las razas New Hampshive, White Leghorn, y posteriormente Rhode Island, se usaron en un programa de cruzamientos.

La Nativa y la White Leghorn fueron eliminadas de la manada experimental, y las líneas existentes en el proyecto en 1955 fueron las siguientes: 1, New Hampshire; 2, cruce entre la New Hampshire y White Leghorn, vuelto a cruzarse con la New Hampshire; 3, cruce con 60 por ciento White Leghorn y 40 por ciento Nativa; 4, Rhode Island; y 5, cruce Rhode Island-New Hampshire.

Una evaluación comparativa entre esas líneas demostró que el cruce Rhode Island-New Hampshire fue superior a las otras, en casi todas las características relacionadas con la producción. Sin embargo, al hacer la comparación entre las líneas del proyecto y las líneas híbridas importadas, no hubo diferencias significativas en cuanto al comportamiento.

Se reveló en este trabajo que la gallina Nativa contribuyó de manera insignificante en lo concerniente a los objetivos del proyecto; también el proyecto demostró que el desarrollo del manejo controlado que se puede utilizar para producir huevos en escala comercial contrapesa las desventajas que surgen debido a las condiciones de clima adversas, lo cual permite el uso de gallinas híbridas importadas a la Isla. 
Se concluye que, siempre que las condiciones controladas puedan mejorarse en las regiones tropicales y subtropicales, esto ofrecería una mayor posibilidad de éxito que los cruces que se hagan para desarrollar la adaptabilidad necesaria para aumentar la productividad de los animales.

\section{LITERATURE CITED}

1. Rhoad, A. O., The dairy cow in the tropics, Amer. Soc. An. Prod. Proc. 28: 212-4, 1935.

2. - Climatic and livestock production, USDA Yearbook, Climate and Man 508-14, 1941.

3. Asmundson, V. S., and Lloyd, W. E., Effect of season on the growth and feed consumption of turkeys, Poultry Sci. 15: 186-, 1936.

4. Kempster, H. L., The influence of summer temperature on the rate of growth of chickens, Poultry Sci. 17: 259-, 1938.

5. Bennion, H. L., and Warren, D. C., Temperature and its effect on egg size in the domestic fowl, Poultry Sci. 12: 69-82, 1933.

6. Warren, D. C., The effect of disturbance upon the rhythm of egg production, .Poultry Sci. 9: 184-, 1930.

7. Lorenz, F. W., and Almquist, H. L., Seasonal variations in egg quality, Poultry Sci. 15: 14-8, 1936.

8. Burrows, W. H., and Byerly, T. C., The effect of certain groups of environmental factors upon the expression of broodiness, Poultry Sci., 17: 324-, 1938.

9. French, M. H., Some observations on poultry, E. African Agr. J. 6: 109-, 1940.

10. Wheatham, E. O., Factors modifying egg production with special references to seasonal changes, J. Agr. Sci. 28: 383-411, 1933.

11. Mann, G. E., Seasonal loss of condition in Rhode Island Red and other fowls in Malaya, Malaya Agr. J. 29: 107-17, 1941.

12. González-Chapel, A., Comparative performance of the Native Puerto Rican fowl, the White Leghorn, the New Hampshire and Crosses between them, J. Agr. Univ. P.R. 4: 265-302, 1947.

13. González Chapel, A., and Rojas Daporta, M., Influence of time of hatching on sexual maturity of pullets in Puerto Rico, J. Agr. Univ. P.R. 95 (3): 100-13, 1951.

14. - Environmental influence on the egg size of pullets in Puerto Rico, J. Agr. Univ. P.R., 36 (2) : 115-21, 1952.

15. Rojas Daporta, M., Basherov, S., and González Chapel, A., Systems of management for Egg Production in Puerto Rico, A Comparative Evaluation of Individual Cages and Several Floor Practices, submitted for publication to the Agricultural Experiment Station of the Univ. of P.R., 1962. 